\title{
V. 地域間の連関構造
}

京都大学 山田浩 之

香川大学 井 原 趾 雄

1. 目 的

この研究は，「地域間産業連関表」を用いて，地域間の相互依存関係を明らかにするととを その目的とする。とくに，3地域に関する一般的后連関モデルを提示し，それに基づく実証分

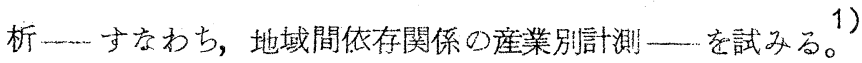

2. 分析飞必要索諸概念

い充，3地域に関する「地域間産業連関表」省前提すれば，乙れに対応して「地域間投入係 数行列」，A索，つ热の上うな小行列低区分するととができる。

(1) $\quad A=\left\{\begin{array}{c:c:c}\ell_{i} & \ell_{j} & \ell_{k} \\ \hdashline A_{i i} & A_{i j} & A_{i k} \\ \hdashline A_{j i} & A_{j j} & A_{j k} \\ \hdashline A_{k i} & A_{k j} & A_{k k}\end{array}\right\} \ell_{i} \ell_{j}$

こてで，Aij は，第 $j$ 地域に和ける第 $i$ 地域産品の投入俰数 $\left(\ell_{i} \times \ell_{j}\right.$ 行列 $)$ 表わする のとする。

さて，とのよらな3地域分割モデルにおいて，地域間投入係数行列におとづく地域間の相互 依存関係を，つぎの 4 つの局面にわけて考察するととができる。

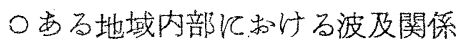

○西地域の生産活動が他の1つの地域に及经吉波及・誘発関係

○ある地域と他の1つの地域との交流関係

○了地域間の交流関係

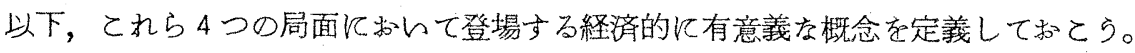

[1]ある地域内部における波及関係

《内部乘数》 
(2) $\left(I-A_{i} i\right)^{-1}=B_{i} i \cdots \cdots \cdot$ 第 $i$ 地域の内部乗数 $\left(\ell_{i} \times \ell_{i}\right.$ 行列 $)$

[2]ある地域の生座活動が他の1つの地域に及哚す波及・誘発関係 《生産誘発係数》

(3)

$$
B_{i i} A_{i j}=\alpha_{i j} \ldots \ldots \ldots \ldots \ldots . . . . . \text { 第 } j \text { 坻域 } \Rightarrow \text { 第 } i \text { 地域の生産誘発係数 }
$$

$\left(\ell_{i} \times \ell_{j}\right.$ 行列 $)$

《投入誘発係数》

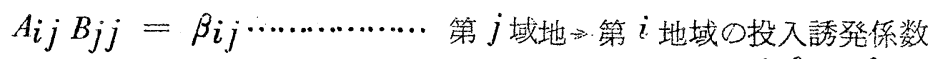

$\left(\ell_{i} \times \ell_{j}\right.$ 行列 $)$

［3］あ地域と他の1つの地域との交流関係

《偏外部乘数》

(5)

$$
\left(I-\alpha_{i j} \quad \alpha_{j i}\right)^{-1}=K_{i i}^{j} \cdots \cdots \text { 第 } i \text { 地域の, 第 } j \text { 地域它経由す当偏外部莱数 }
$$

$$
\left(\ell_{i} \times \ell_{i} \text { 行列 }\right)
$$

《编レオンチェフ乘数》

(6) $\quad K_{i i}^{j} B_{i i}=M_{i i}^{j}$

第 $i$ 地域の偏レオンチェフ乗数 $\left(\ell_{i} \times \ell_{i}\right.$ 行列 $)$

[4] 3 地域間の交流関係

《複投入係数》

(7)

$$
\begin{array}{r}
A_{i j}+A_{i k} B_{k k} A k j=A_{i j}^{k} \cdots \cdots \text { 第 } j \text { 地域飞郝海第 } i \text { 地域座 } \\
\text { 数 }\left(\ell_{i} \times \ell_{j} \text { 行列 }\right)
\end{array}
$$

《袙生産誘発係数》

(8)

$$
M_{i i}^{k} A_{i j}^{k}=\alpha_{i j}^{k} \ldots . . . . . . . . . . . . \text { 第 } j \text { 地域 } \rightarrow \text { 第 } i \text { 地域の複生座誘発係数 }
$$

$\left(\ell_{i} \times \ell_{j}\right.$ 行列 $)$

\section{《複投入誘発係数》}

(9)

$$
A_{i j}^{k} M_{j j}^{k}=\beta_{i j}^{k}
$$

第 $j$ 地域 $\rightarrow$ 第 $i$ 地域の複投入誘発係数

$$
\left(\ell_{i} \times \ell_{j} \text { 行列 }\right)
$$

《複外部乗数》

(10)

$$
\left(I-\alpha_{i j}^{k} \alpha_{j i}^{k}\right)^{-1}=\bar{K}_{i i}^{k} \cdots \text { 第 } i \text { 地域の複外部乗数 }\left(\ell_{i} \times \ell_{i} \text { 行列 }\right)
$$

《総外部乗数》

(11)

$$
\left\{I-B_{i i}\left(A_{i k} B_{k k} A_{k i}+A_{i j}^{k} M_{j j}^{k} A_{j i}^{k}\right)\right\}^{-1}=\overline{\bar{K}}_{i i} \ldots \ldots \ldots
$$

第 $i$ 地域の総外部乗数 $\left(\ell_{i} \times \ell_{i}\right.$ 行列 $)$ 
《レオンチェフ乗数》

612

$$
(I-A)^{-1}=C=\left[\begin{array}{cc:c}
\ell_{i} & \ell_{j} & \ell_{k} \\
\hdashline c_{i i} & c_{i j} & c_{i k} \\
\hdashline c_{j i} & c_{j j} & c_{j k} \\
\hdashline c_{k i} & c_{k j} & c_{k k}
\end{array}\right\} \ell_{i}
$$

3. モデルの数学的椿造

以上の諸概念老用いて，レオンチェフ乗数の分解，表示冠行京小ら。

まず，3地域に分割した地域間産業連関モデルは次式のように示される。

(13) $\left[\begin{array}{c}X_{1} \\ X_{2} \\ X_{3}\end{array}\right]=\left[\begin{array}{lll}A_{11} & A_{12} & A_{13} \\ A_{21} & A_{22} & A_{23} \\ A_{31} & A_{32} & A_{33}\end{array}\right]\left[\begin{array}{c}X_{1} \\ X_{2} \\ X_{3}\end{array}\right]+\left[\begin{array}{c}F_{1} \\ F_{2} \\ F_{3}\end{array}\right]$

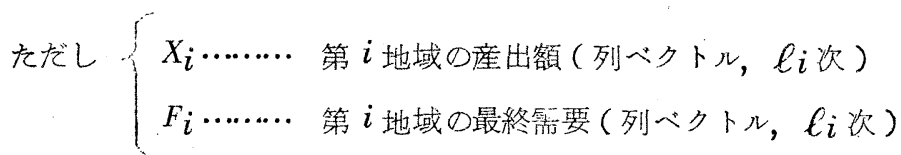

そして，との連立方程式体系の解は次のように示されるが，

$(14)\left[\begin{array}{c}X_{1} \\ X_{2} \\ X_{3}\end{array}\right]=\left[\begin{array}{lll}C_{11} & C_{12} & C_{13} \\ C_{21} & C_{22} & C_{23} \\ C_{31} & C_{32} & C_{33}\end{array}\right]\left[\begin{array}{c}F_{1} \\ F_{2} \\ F_{3}\end{array}\right]$

前節で定義した諸概念を用いて，乙の連立方程式体系を解いていくならば，逆行列係数 $C ，$ すなわちレオンチェフ乘数にたいして，次に示すょらな，んくつかの代替的な表現形式をあた えるととがでをる。

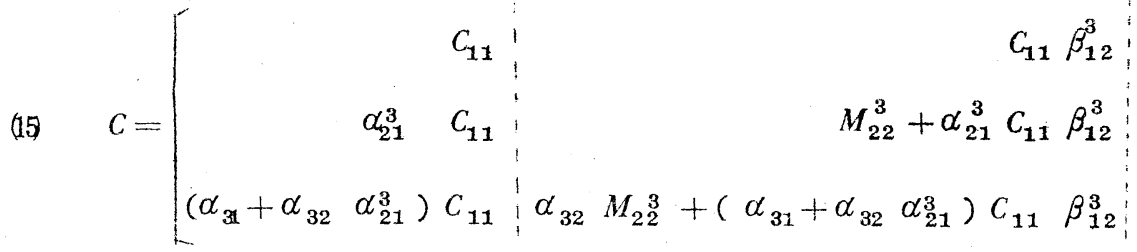




$$
\begin{aligned}
& C_{11}\left(\beta_{13}+\beta_{12}^{3} \beta_{23}\right) \\
& M_{22}^{3} \beta_{23}+\alpha_{21}^{3} C_{11}\left(\beta_{13}+\beta_{12}^{3} \beta_{23}\right) \\
& \left.B_{33}+\alpha_{32} M_{22}^{3} \beta_{23}+\left(\alpha_{31}+\alpha_{32} \alpha_{21}^{3}\right) C_{11}\left(\beta_{13}+\beta_{12}^{3} \beta_{23}\right)\right] \\
& (16)=\left[\begin{array}{rr:r:r:r}
\overline{\bar{K}}_{11} & B_{11} & \overline{\bar{K}}_{11} & B_{11} \beta_{12}^{3} & \overline{\bar{K}}_{11} B_{11} \beta_{13}^{2} \\
\alpha_{21}^{3} \overline{\bar{K}}_{11} & B_{11} & M_{22}^{3}+\alpha_{21}^{3} \overline{\bar{K}}_{11} B_{11} \beta_{12}^{3} & M_{22}^{3} \beta_{23}+\alpha_{21}^{3} \overline{\bar{K}}_{11} B_{11} \beta_{13}^{2} \\
\alpha_{31}^{2} \overline{\bar{K}}_{11} & B_{11} & M_{33}^{2} \beta_{32}+\alpha_{31}^{2} \overline{\bar{K}}_{11} B_{11} \beta_{12}^{3} & M_{33}^{2}+\alpha_{31}^{2} \overline{\bar{K}}_{11} B_{11} \beta_{13}^{2}
\end{array}\right] \\
& \text { (11) }=\left[\begin{array}{rl:r:r}
C_{11} & C_{11} \beta_{12}^{3} & C_{11} \beta_{13}^{2} \\
\alpha_{21}^{3} C_{11} & M_{22}^{3}+\alpha_{21}^{3} C_{11} \beta_{12}^{3} & M_{22}^{3} \beta_{23}+\alpha_{21}^{3} C_{11} \beta_{13}^{2} \\
\alpha_{31}^{2} C_{11} & M_{33}^{2} \beta_{32}+\alpha_{31}^{2} C_{11} \beta_{12}^{3} & M_{33}^{2}+\alpha_{31}^{2} C_{11} \beta_{13}^{2}
\end{array}\right) \\
& (18)=\left[\begin{array}{cc:cc:cc} 
& C_{11} & \alpha_{12}^{3} & C_{22} & \alpha_{13}^{2} & C_{33} \\
\alpha_{21}^{3} & C_{11} & & C_{22} & \alpha_{23}^{1} & C_{33} \\
\alpha_{31}^{2} & C_{11} & \alpha_{32}^{1} & C_{22} & & C_{33}
\end{array}\right] \\
& 49=\left[\begin{array}{ll:ll:ll}
C_{11} & & C_{11} & \beta_{12}^{3} & C_{11} & \beta_{13}^{2} \\
C_{22} & \beta_{21}^{3} & C_{22} & C_{22} & \beta_{23}^{1} \\
C_{33} & \beta_{31}^{2} & C_{33} & \beta_{32}^{1} & C_{33}
\end{array}\right)
\end{aligned}
$$

とのようなレオンチェフ乗数の代替的な分解・表示方式から, 諸概念相互間の関係に注目す

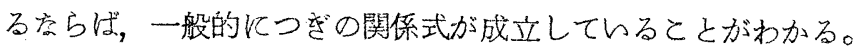

まず，自地域内波及の総效果を示す逆行列係数，すなわち上で与えたレオンチェフ乗数のう ち，対角線上飞ある $c_{i i}$ につては,

20

$$
\begin{aligned}
C_{i i} & =\overline{\bar{K}}_{i i} B_{i i} \\
& =\bar{K}_{i i}^{k} M_{i i}^{k}={\overline{K_{i}}}_{i}^{j} M_{i i}^{j} \\
& =\bar{K}_{i i}^{k} K_{i i}^{k} B_{i i}=\bar{K}_{i i}^{j} K_{i i}^{j} B_{i i}
\end{aligned}
$$




$$
\begin{aligned}
& =M_{i i}^{k}+\alpha_{i j}^{k} C_{j j} \beta_{j i}^{k}=M_{i i}^{j}+\alpha_{i k}^{j} C_{k k} \beta_{k i}^{j} \\
& =B_{i i}+\alpha_{i k} M_{k k}^{i} \beta_{k i}+\alpha_{i j}^{k} C_{j j} \beta_{j i}^{k} \\
& =B_{i i}+\alpha_{i j} M_{j j}^{i} \beta_{j i}+\alpha_{i k}^{j} C_{k k} \beta_{k i}^{j}
\end{aligned}
$$

また，地域間交叉効果を示す逆行列係数，すをわちレオンチェフ乗数のうち非詨角線上にあ るCijについては,

(21)

$$
\begin{aligned}
C_{i j} & =\alpha_{i j}^{k} C_{j j}=C_{i i} \beta_{i j}^{k} \\
& =\alpha_{i j} M_{j j}^{i}+\alpha_{i k}^{j} C_{k k} \beta_{k j}^{i}=M_{i i}^{j} \beta_{i j}+\alpha_{i k}^{j} C_{k k} \beta_{k j}^{i}
\end{aligned}
$$

\section{4. 逆行列係数分解分析の意義}

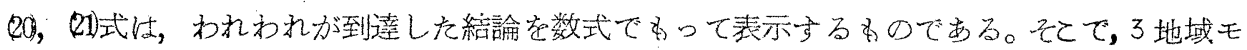
デルに晾る逆行列係数の分解分析の的意義を検剷しておてう。

まず第 1 亿，逆行列係数す存わちレオンチェフ乗数恃，自地域内の波及効果と他地域を経由 する波及効果とを集計する究極的総効果でするととが明示的飞表現されているが，さらにそれ は，すでに定義した諸概念を用いて稳の形によってわ，まを和の形によっても表示されるとと が示されている。

すなわち，積の形で自地域総効果を示すわのとしては，(a)「総外部乗数 $\times$ 内部乗数」あるん は，(b)「複外部莱数 $\times$ 偏レオンチェフ乘数」のでとく分解するととわ可能であれば，(c)の上う 飞「複外部乘数 $\times$ 偏外部乗数 $\times$ 内部乗数」といら形にる分解でをるととがわかる。そして，と れらと対応して，たとえば(b)飞対応しては(b)の上5に「2地域内部波及効果（偏レオンチェフ

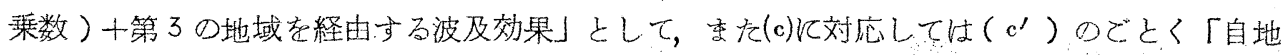
域波及効果十第 2 の地域を経由する波及勃果十第 3 の地域を経由する波及効果」として，“和の 形で分解・表示するととがでをるのである。

そこから，偏外部乗数 $K_{i i}^{j}$ は「第 2 の地域を経由する波及効果」を，複外部乗数 $\bar{K}_{i i}^{j}$ 㳉

「第了の地域を経由する波及效果」を，内部菜数に対する乗数の形でとらえたるのに他索らな らととが明らかとなる。してがって，総外部乘数 $\bar{K}_{i i}$ はとれら双方の効果学集計したかのと して，「複外部乗数×偏外部乗数」すなわち $\bar{K}_{i i}^{j} \times K_{l i}^{j}$ の形でとらえるととがでをるの である。 
地域間交文効果につんて子同様に，(a)「複生産誘発係数入波及の初発点と存る地域の自地域 総効果」あるい波及在受ける地域の自地域総効果×複投入誘発係数」といら積の形でとらえ

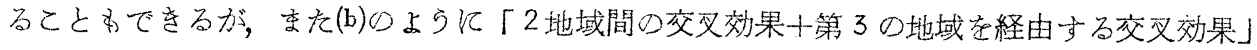
という和の形によってもとらえることができるのである。

第 2 ，逆行列倸数が幾通りかの代替的な表現形式をとるととによって，地域間依存関係の 計量的な比較検討ふ河能となるととがあげられる。

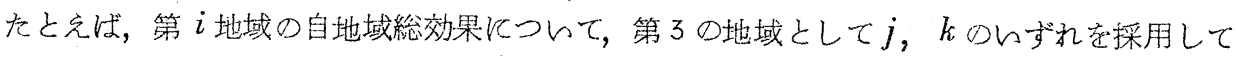
わ，その総効果壮同じとなるととが明示されているととから，2地域間の相互依存関係の强度

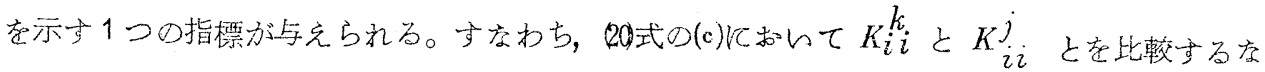
ら壮，第 $i$ 地域が管 $k$ 地域と第 $j$ 地域のいずれと，より相互依存度が高いかが判定される。と ころで, $\bar{K}_{i i}^{k} K_{i i}^{k}=\bar{K}_{i i}^{j} K_{i i}^{j}=\bar{K}_{i i}$ であるから, $\bar{K}_{i i}^{k}, \bar{K}_{i i}^{j}$ は, $K_{i i}^{k}, K_{i i}^{j}$ 補整す

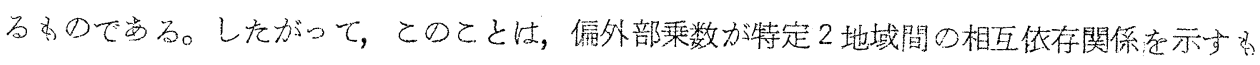

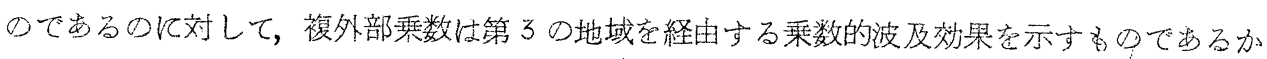
b， $i$ 一地域間の結合度が $i$ 一地域間のそれより強くなれば，当然 $\bar{K}_{i i}^{k}$ 之 $\bar{K}_{i i}^{j}$ とは 逆敒作用するとと竞意味する。

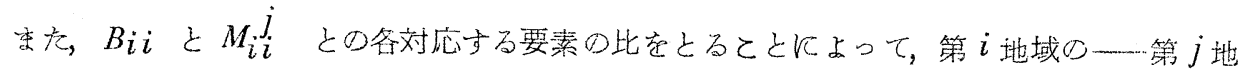

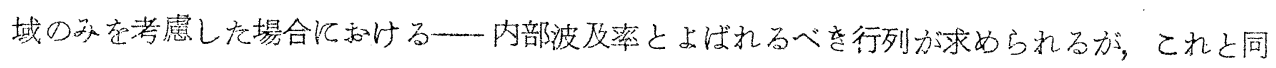
様にして， $B_{i i}$ と $C_{i i}$ との対応する要素の比をとるととにょって，第 $i$ 地域の-...-第 $j \cdot k$

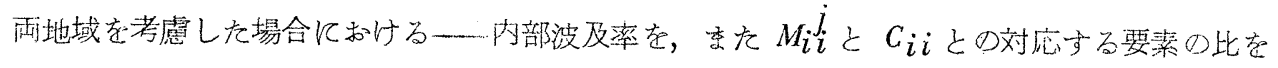

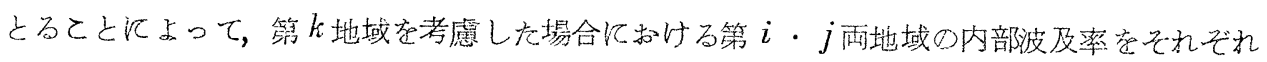
求めるととができる。

さらにをた，3地域分割モデルに劼ける交流関係を簡明に把握するための概念として，われ われ複投入係数》を提案し，てれ它一般的な形として(7)式で与えて和々た。それはつざの ように解釈でをよう。すなわち, (7)式左辺の第 2 項は, 第 $j$ 地域の第 $k$ 地域座品の投入によ。 て誘発される第 $k$ 地域の内部波及が必要とする第 $i$ 地域産品の投入であり，したがって(7)式の

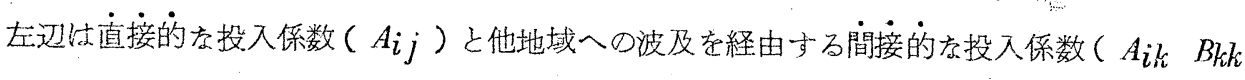
$A k j)$ と和であり，全体として他の1つの地域への波及を考虑したある地域の投入係数を意 昧するまのと考えられる。それゆえ， $A_{i j}$ と $A_{i j}^{k}$ と孝比較するてとによって，第 $k$ 地域军

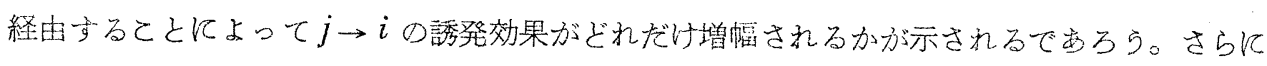
また，との複投入係数にもとづ複生産誘発係数，複投入誘発係数を(8)，(9)式のょらに求める 


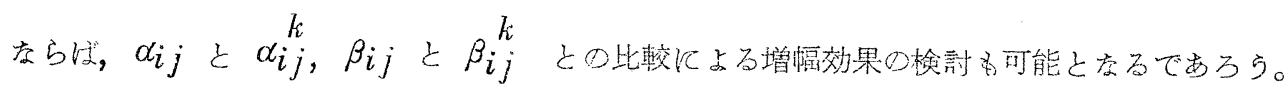

5. 地域間㑈存関係の産業別計測 3 )

ここで，通産省か作製した「昭和３５年地域間産業連関表」に詨し，われわれの「3地域分 割モデル」を適用してみよう。利用しを連関表姑，全国9地域10部門㝨としててをとめられた わのである。 われわれは9地域のうちから，近織，東海，関東のる地域をえらび，乙れらろ

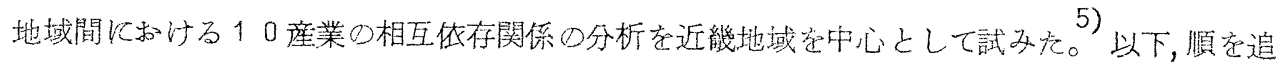

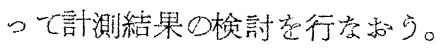

[1] 当地域内部に和ける波及関係

(i) 内部乗数に上る分析

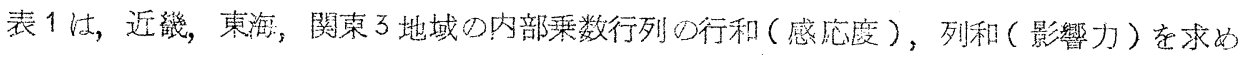
たものである。てれによれば，3地域のなかでは関東の内部采数効果が最わ大きく，総平均で みて174.6\%を宗している。とれにつぐのが近畿の172.0\%で，東海地域の内部乘数効果

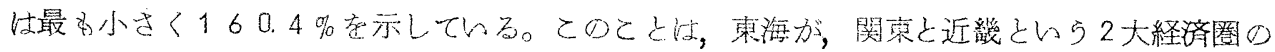

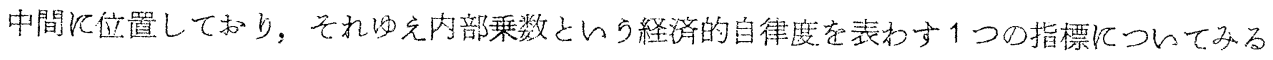

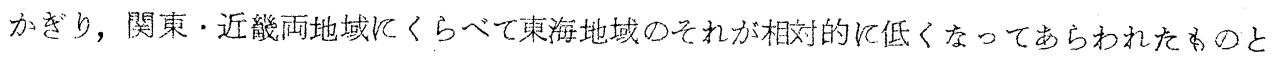
解釉できる。

表 1 内 部乗 数

\begin{tabular}{|c|c|c|c|c|c|c|}
\hline \multirow{2}{*}{ 部門地 域 } & \multicolumn{2}{|c|}{ 近 幾 $\left(B_{11}\right)$} & \multicolumn{2}{|c|}{ 東 海 $\quad\left(B_{22}\right)$} & \multicolumn{2}{|c|}{ 関 東 $\quad\left(B_{33}\right)$} \\
\hline & 感応㝗 & 影響 才。 & 感 広 度 & 影㗽力 & 感 応度 & 影 響 力 \\
\hline 農 林 水甠 & 174.0 & 146.5 & 199.9 & 148.0 & 183.0 & 146.1 \\
\hline 菜 & 121.9 & 144.9 & 125.2 & 141.7 & 13.3 .1 & 145.3 \\
\hline 維 & 141.5 & 189.2 & 158.2 & 205.7 & 130.9 & 173.1 \\
\hline 化 & 160.0 & 172.4 & 150.1 & 177.9 & 172.4 & 189.0 \\
\hline 属 & 258.6 & 2.18 .5 & 159.3 & $15 \% .2$ & 242.5 & 213.7 \\
\hline 機 & 153.7 & 187.7 & 146.0 & 158.6 & 171.4 & 194.5 \\
\hline その他の製造䒹 & 177.9 & 177.9 & 162.4 & 181.7 & 184.7 & 192.5 \\
\hline 設 & 112.0 & 192.7 & 112.9 & 161.9 & 113.0 & 191.6 \\
\hline 輸 & 134.7 & 143.7 & 127.6 & 131.4 & 134.8 & 152.0 \\
\hline 他 & 285.4 & 146.2 & 262.2 & 137.9 & 280.1 & 148.0 \\
\hline (平 & 172.0 & 172.0 & 160.4 & 160.4 & 174.6 & 174.6 \\
\hline
\end{tabular}


また，乙の内部乘数を座業別に検討すれ壮，影響力の分散よりも感応度の分散の方が大をく なっている。乙れは，感応度自体が産業の性格によってかなり大きく左右されるというととの 反映と考えられる。たとえば，影響力・感応度の両方を通じて，金属産業の感応度が，近盏・ 関東の両地域を通じて最わ高い。とれと朔に，建設業のそれは当該了地域とも最低を示して 施

さらに注目すべをとととして，近織・関東雨地域の経済的内部構造が非常に類似しているの に対し，東海地域のそれが前二者とはかなり様相を異にしているといら事実である。とれを哑 つけるタのとしては，近钱・関東両地域に利ける金属産業の子つウェイトにくらへて，東海地 域のそれが著しく低く平均以下に落ちているとと，さらにまた東海地域に利ける瀻維産業の占 ぬる影響力が最わ高いとんったととなどが指摘できるであるう。

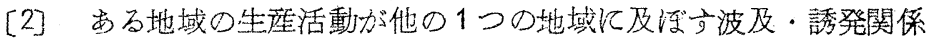

(ii) 生産誇発係数による分析

そこでつぎに，近緖を中心とした他の特定1地域のみとの相互依存関係を考察するととにし よう。表 2 は, 東海・関東両地域の各産業が, 近械地域産品を投入するととによって近畿地域に 与える内部波及効果，守等指ち生産誘発係数の計測結果要約的に表示したるのである。

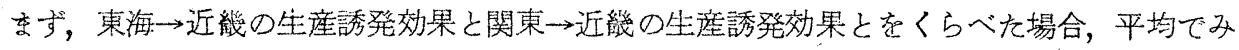
て前者が $0.94 \%$ ，後者が0.79\%となっている。このととは，東海の発注による近畿への特

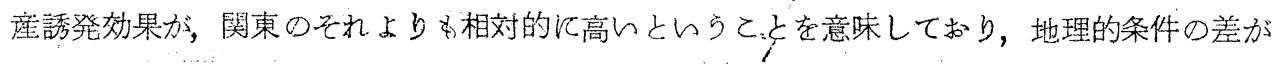
反映されているとみるととがでさる。そてでててれ各産業別に検討しょら。

袁 2 生塺誘発係数表 $\alpha_{i j}=B_{i} i A_{i j}$ (単位 \%)

\begin{tabular}{|c|c|c|c|c|}
\hline \multirow{2}{*}{ 部閶填自 } & \multicolumn{2}{|c|}{ 近㜻 $\leftarrow$ 東 海 $\left(\alpha_{12}\right)$} & \multicolumn{2}{|c|}{ 近链 } \\
\hline & 行 平 均 & 列平均 & 行平均 & 列平均 \\
\hline 䢅林，水 産 & 0.45 & 0.20 & 0.37 & 0.19 \\
\hline 鉣: & 0.17 & 0.11 & 0.12 & 0.04 \\
\hline 繊 & 1.10 & 1. 70 & 1. 41 & 2. 42 \\
\hline 化: & 1. 07 & 0.37 & 0.84 & 0.37 \\
\hline 金 & 3. 13 & 1. 47 & 2.11 & 0.98 \\
\hline 械 & 0.87 & 1. 95 & 0.74 & 1. 50 \\
\hline その他の製造業 & 0.98 & 0.80 & 0.81 & 0.50 \\
\hline 建 & 0.05 & 2.02 & 0.04 & 1.31 \\
\hline : : & 0. 28 & 0.35 & 0.14 & 0.30 \\
\hline$z \quad 0 \quad$ 他 & 1. 33 & 0.46 & 1.34 & 0.31 \\
\hline 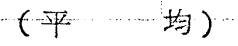 & 0.94 & 0.94 & 0.79 & 0.79 \\
\hline
\end{tabular}




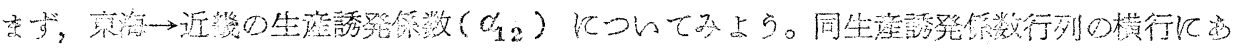

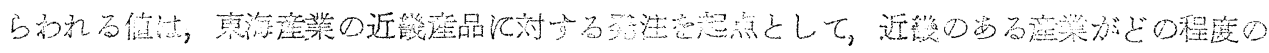

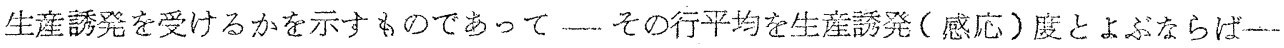

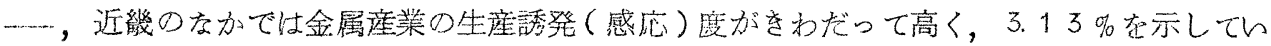

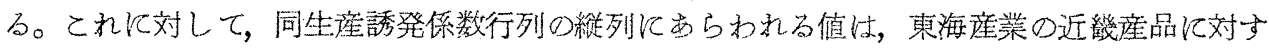
る発注を起点として，東海のある産業が近㭜の各座業に詨してどの程度の生座誘発をあたえる

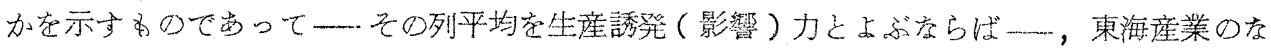

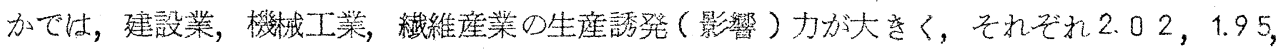
1. $70 \%$ と学っている。

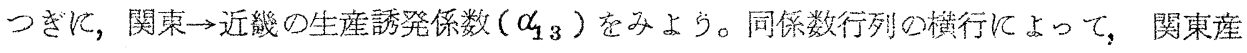

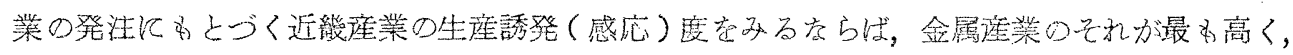

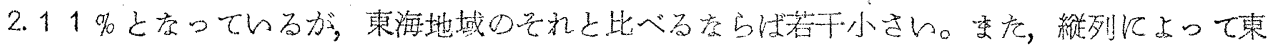

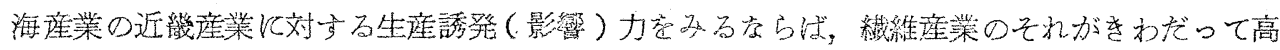
く, $2.42 \%$ k達している。

(iii) 投入誘発係数化上万分析

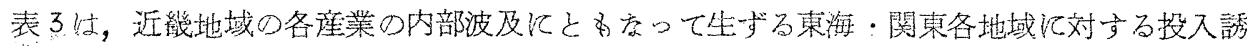

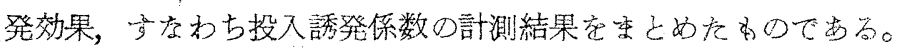

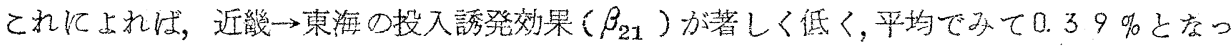

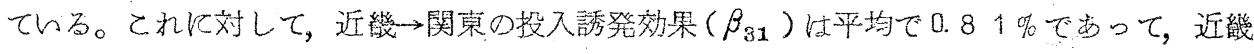

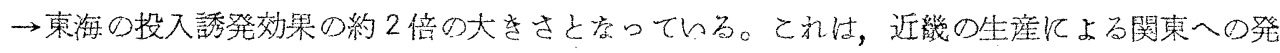

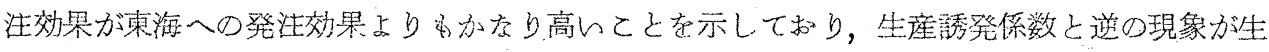

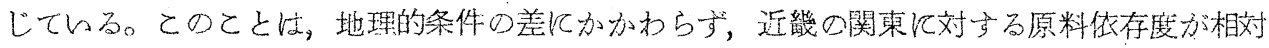

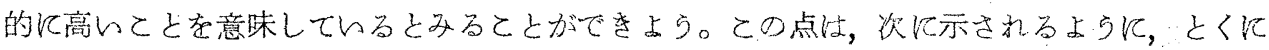

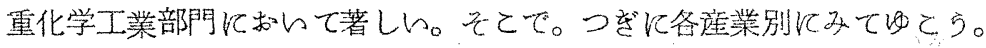

まず，近畿 $\rightarrow$ 東海の投入諉発係数行列 $\left(\beta_{21}\right)$ の横行にあられれる值は，近畿の座業活動を 起点として，東海のある産業がどの程度の発注を受けるか子示するのであるから一一の行平

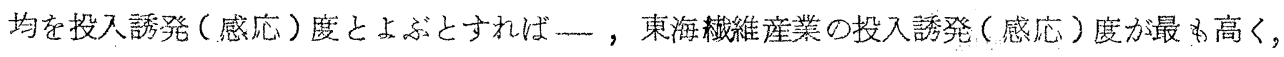
1. $28 \%$ を示しているが, 化学産業の0.85\%を除んて他は比較的小さん。てれに対して, 同

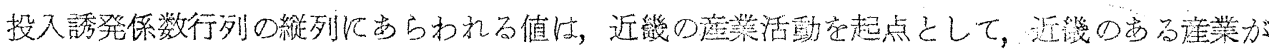

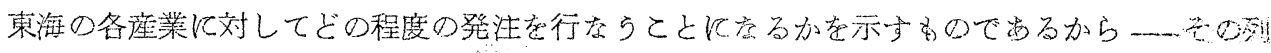


平均を投入誘発 (影響) カとよぶとすれげ—，近畿の産業の中では繊維産業が $1.36 \%$ とを わ立って高い值を示しているが，他は小さん。これらから，近綿の東海に対する原料依存度は，

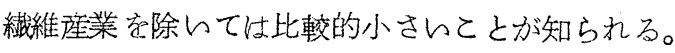

表 3 投入誘発保数表 $\quad \beta_{i j}=A_{i j} B_{j j}$ (単位 \%)

\begin{tabular}{|c|c|c|c|c|}
\hline \multirow{2}{*}{ 部 ${ }$ 門肔項首 } & 東 海 & I 綗 $\left(\beta_{21}\right)$ & 関 東 Ł & 近 畿 $\left(\beta_{31}\right)$ \\
\hline & 行 平均 & 列 平均 & 行 平 均 & 列 平 均 \\
\hline 農 林 水 産 & 0.09 & 0.12 & 0.81 & 0.36 \\
\hline 䥔 & 0.01 & 0. 13 & 0.03 & 0.23 \\
\hline 絊 & 1. 28 & 1. 36 & 0.67 & 0.92 \\
\hline 化 & 0.85 & 0.30 & 1. 43 & 0.83 \\
\hline 金 & 0.39 & 0.24 & 1.67 & 0.92 \\
\hline 機 & 0.44 & C. 56 & 1.60 & 1. 63 \\
\hline その他の製造業 & 0.54 & 0.33 & 1.07 & 1.06 \\
\hline 設 & 0.00 & 0.46 & 0.00 & 1. 18 \\
\hline 運 & 0.01 & 0.23 & 0.09 & 0.49 \\
\hline$\infty$ & 0.34 & 0.20 & 0.72 & 0.45 \\
\hline 均) & 0.39 & 0.39 & 0.81 & 0.81 \\
\hline
\end{tabular}

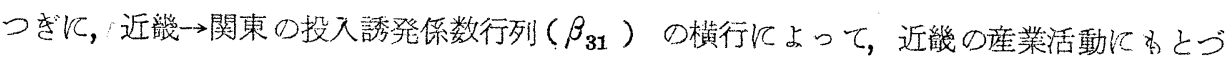
く関東産業の投入誘発（感応）度をみるならば，金属・機械・化学の各産業の值が高く，それ

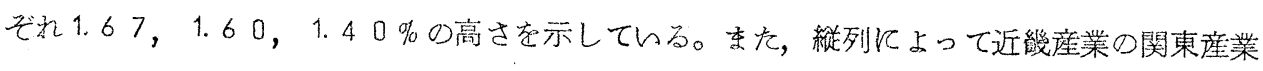

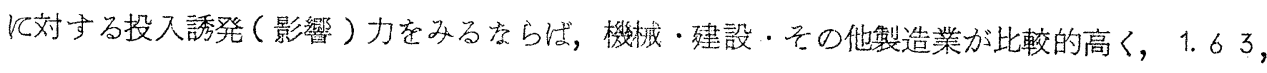
$1.18 ， 1.08 \%$ の值を示している。このととから, 近幾の関東に対する原料依存度は重化学 工業の面に叔て高いととがわかる。

以上におらて，近载を中心として，近畿と他の特定 1 地域の夕との局部的相互依存の関係を， 生産誘発係数行列（表２）・投入誘発係数行列（表了）に上って分析してきたが，乙れらを地 域間の結合関係を中心に，次のょうにをとめるととがでさる。

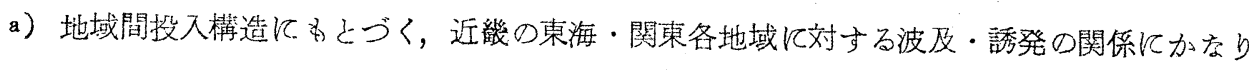
顕著卖筫的差暴が存在する。

b）まず，近畿一東海の局部的相互依存の関係に限定すれば，その生産誘発効果はか疗り高く， 平均で $0.94 \%$ を示しているのに対し，その投入誘発奻果は著しく低く平均で0.39\% と索 
ってレる。さらに，ての前者につレては，近幾の金属産業の受ける効果が汇倒的に高く，後 者につレては近畿・東海の㼄維産業がんずれる相対的に重要な機能を果している。

図 1. 生举誘発効果

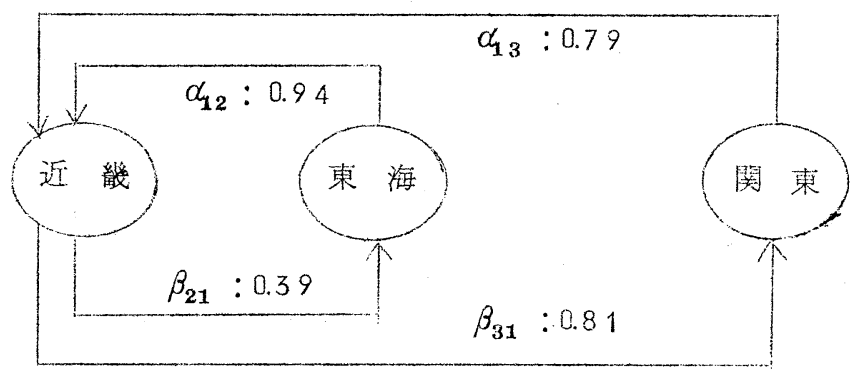

投入誘発効果

c）つ豆に，近畿一関東の局部的相互依存の関係に限定して考えるならば，その生産誘発効果

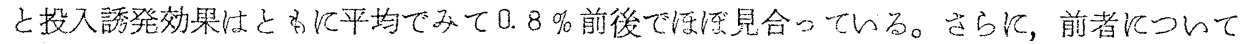

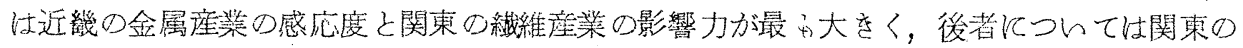

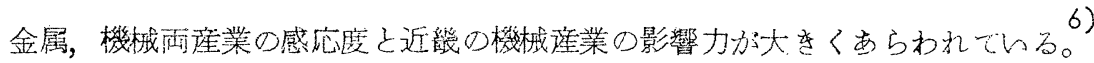

[3]专当地域之他の1つの地域との交流関係

(iv) 偏外部乗数に上る分析

ここで， $i \cdot j$ 特定 2 地域のみの交流関係を一括して検討するととにしょう。いま， $i$ 地域

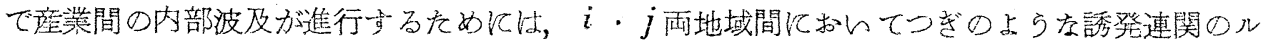

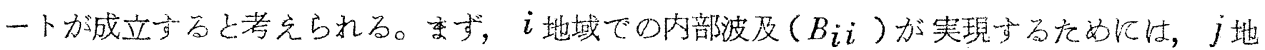
域産品の投入 $(A j i)$ が必要となり，弪の結果，j地域での生産すなわちその内部波及( $B j j)$ が誘発される。つ忞に，乙のj地域での生産が行をわれるためには， $i$ 地域産品の投入 $\left(A_{i j}\right)$ が要請され，それは $i$ 地域内部での座業間波及( $\left.B_{i i}\right)$ ）誘発主る。そしててれはふたたび $j$ 地域産品の投入 $\left(A_{j i}\right)$ を要求し，乙の波及過程が収束するまでくりかえされるととになる。 つまり，乙のてとは $B_{i i} A_{i j} B_{j j} A_{j i}=\alpha_{i j} \alpha_{j i}$ 波及因子とする乗数過程が $i$ 地域には放か えって生ずるてと意味する。したがってわれわれはての究極的な乘数桩大効果を偏外部媇数 とよび，てれを(5)式のょうと定義したわけである。 
表 4 霹外部舞数

$K_{i j}^{j}=\left(I-\alpha_{i j} \alpha_{i i}\right)^{-1}$

(兴位 $\%$ )

\begin{tabular}{|c|c|c|c|c|}
\hline \multirow{2}{*}{ 部門項昌 } & \multicolumn{2}{|c|}{ 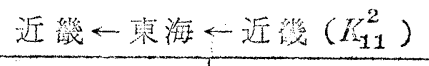 } & \multicolumn{2}{|c|}{ 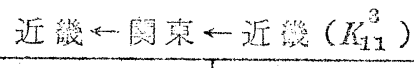 } \\
\hline & 感 応度 & 影籍 力 & 感庆变 & 影㗽力 \\
\hline 壆林水産 & 100.3 & 100.1 & 100.3 & 100.1 \\
\hline 業 & 100.1 & 100.1 & 100.1 & 100.0 \\
\hline 緎 & 101.3 & 102.3 & 100.9 & 1013 \\
\hline 化 & 100.6 & 100.2 & 100.8 & 100.4 \\
\hline 金 & 100.9 & 100.2 & 102.5 & 10.7 \\
\hline 械 & 100.3 & 100.9 & 100.7 & 102.4 \\
\hline その他の製造業 & 100.4 & 100.2 & 100.7 & 100.5 \\
\hline 設 & 100.0 & 100.5 & 100.0 & 101.3 \\
\hline 翰 & 10.0 .1 & 100.1 & 100.1 & 100.2 \\
\hline D 他 & 100.7 & 100.2 & 101.2 & 100.3 \\
\hline (平均) & 100.5 & 100.5 & 100.7 & 100.7 \\
\hline
\end{tabular}

表 4 は，近畿の束海・関東各地域を経由する偏外部乘数の計剆結果である。まず， $K_{11}^{2}$ ，

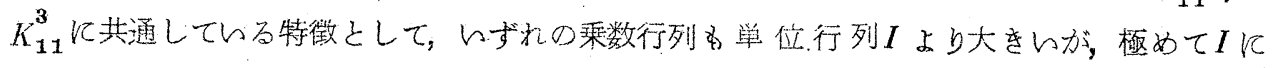
近んといらととが指摘できる。をとえば，

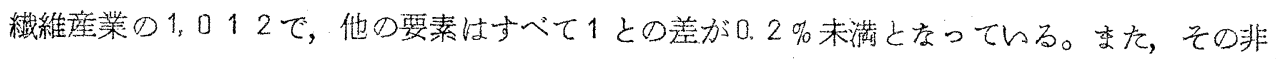

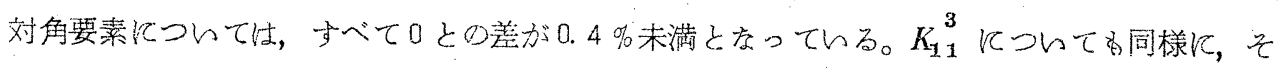

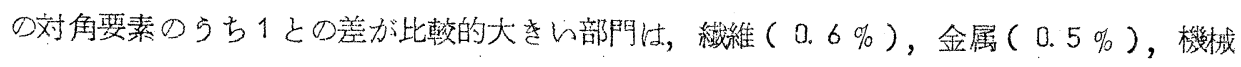

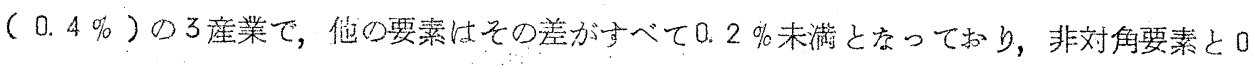

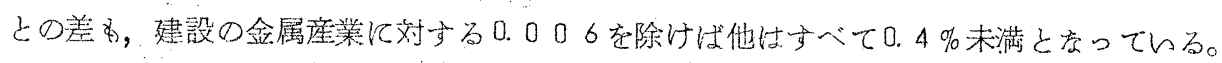

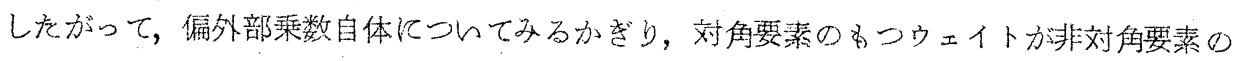

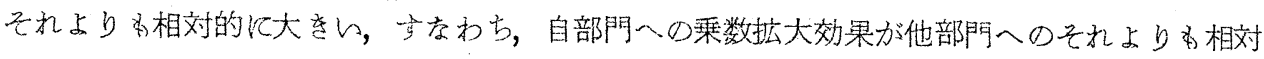

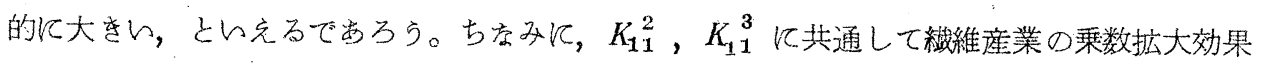

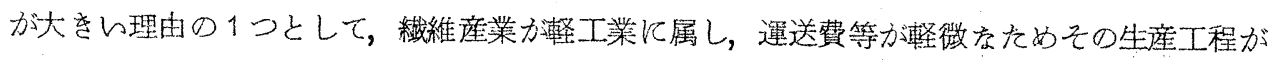
地域分散型飞字りらるといった点が考えられよう。

(V) 偏レオンチェフ乘数による分析

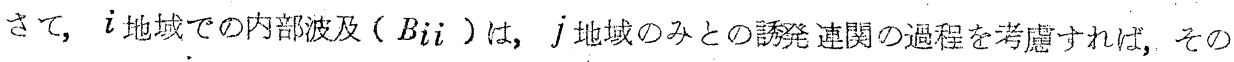

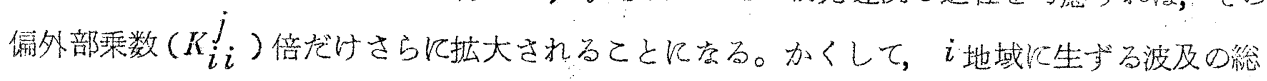


効果は， $i \cdot j$ 特定 2 地域に考察老限定するが゙り，(6)式のように与えられるであるら。表 5

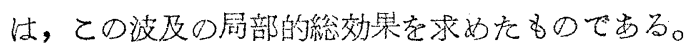

表 5 偏レオンチエフ乘数

$$
M_{i i}^{j}=K_{i i}^{j} B_{i i} \quad \text { (単位\%) }
$$

\begin{tabular}{|c|c|c|c|c|}
\hline \multirow{2}{*}{ 地垉直 } & \multicolumn{2}{|c|}{ 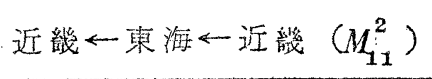 } & \multicolumn{2}{|c|}{ 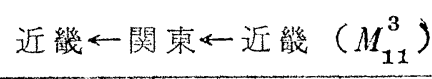 } \\
\hline & 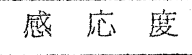 & 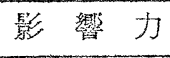 & 壂庆度 & 影 響 力 \\
\hline 䣮 林 水 㢈 & 174.4 & 146.6 & 174.4 & 146.8 \\
\hline 鉱業 & 122.0 & 145.1 & 122.1 & 145.2 \\
\hline 纎 & 143.5 & 192.4 & 142.9 & 191.2 \\
\hline 化 & 161.0 & 172.7 & 161.3 & 173.1 \\
\hline 属 & 260.0 & 218.9 & 262.9 & 220.0 \\
\hline 機 & 154.1 & 188.9 & 154.8 & 190.9 \\
\hline その他の製造業 & 178.5 & 178.3 & 179.0 & 178.8 \\
\hline 建 & 112.1 & 193.4 & 112.1 & 194.6 \\
\hline 運 & 134.8 & 143.9 & 134.9 & 144.2 \\
\hline$\varnothing$ & 286.4 & 146.6 & 287.3 & 146.8 \\
\hline (平 均) & 172.7 & 172.7 & 173.2 & 173.2 \\
\hline
\end{tabular}

われわれは，すでに近䋐の菓海・関東老経由する偏外部乗数 $\left(K_{11}^{2}, K_{11}^{3}\right)$ がをわめて単位

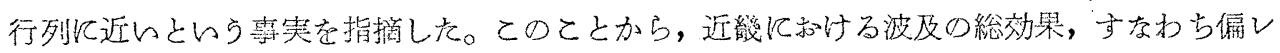
サンチエフ重数 $\left(M_{11}^{2}, M_{11}^{3}\right)$ は，在とんぞ近禨に和汀る内部乘数 $\left(B_{11}\right)$ によって決定され

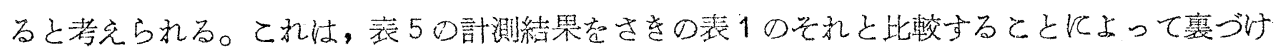

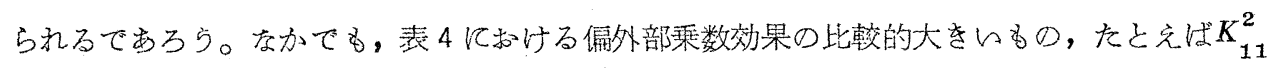

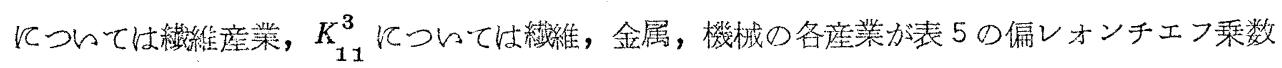

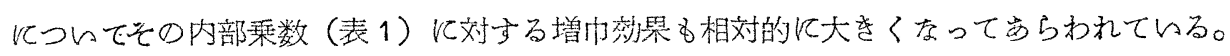

〔4]3 地域間の突流関保

(Vi) 内部波及率に上る分析

最後に，地域間相互の依存関係を特定 2 地域の夕の交流関係に限定するととなく，さらに第

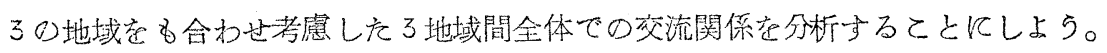

こてていう内部波及率とは，(2)で与え汒内部乘数行列の各要素を（12）で与えて了地域内の 
総波及乗数行列の同位圆の要素で割ったものであり，したがっててれは，3池域間の艾流関係

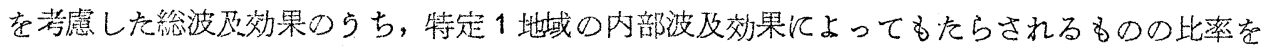
示すととになる。表6は，とれ实了地域についてそれぞれ求めたものである。これによれば，

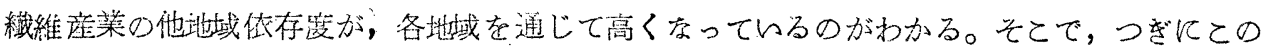
点考各要素について吟味してみよう。

表6内部波及率

（算位\%）

\begin{tabular}{|c|c|c|c|c|c|c|}
\hline \multirow{2}{*}{ 部門具 } & \multicolumn{2}{|c|}{ 近 繼 $\left(B_{11} / C_{11}\right)$} & \multicolumn{2}{|c|}{ 東 海 $\left(B_{22} / C_{22}\right)$} & \multicolumn{2}{|c|}{ 関 東 $\left(B_{33} / C_{33}\right)$} \\
\hline & 行平均 & 列平均 & 行平均 & 列平均 & 行平均 & 列平均 \\
\hline 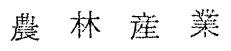 & 97.3 & 97.8 & 96.7 & 97.9 & 95.5 & 97.3 \\
\hline 鉣 & 97.0 & 97.9 & 96.1 & 97.3 & 95.7 & 97.7 \\
\hline 維 & $8 \% 5$ & 93.9 & 85.7 & 93.8 & 90.5 & $8 \% 1$ \\
\hline 化 & 95.8 & 97.0 & 93.0 & 97.2 & 94.4 & 97.7 \\
\hline 金 & 93.4 & 96.4 & 93.9 & 95.1 & 93.5 & 95.6 \\
\hline 树 & 97.3 & 93.4 & 97.5 & 92.0 & 96.1 & 93.4 \\
\hline その他の整造潥 & 97.0 & 96.7 & 96.8 & 97.0 & 96.5 & 97.2 \\
\hline 建 & 98.9 & 96.8 & 99.1 & 95.5 & 98.6. & 96.2 \\
\hline 運 & 98.9 & 96.5 & 99.2 & 95.1 & 98.6 & 96.3 \\
\hline 他 & 98.4 & 96.8 & 98.8 & 95.8 & 97.9 & 96.9 \\
\hline 均) & 96.4 & 96.4 & 95.7 & 95.7 & 95.7 & 95.7 \\
\hline
\end{tabular}

いま，内部波及率の行平均・列平均をそれぞれ感応内蔀波及率，影響内部波及率とよぶて

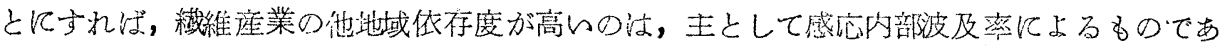
って，影響内部波及率による效果㤌小さん，といらてとができる。たとえげ，近幾の内部波

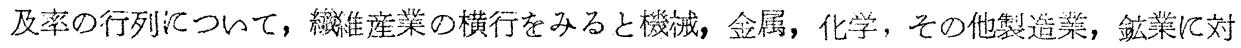

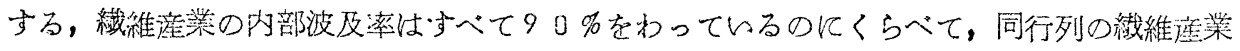
の縦列定みると内部波及率で90\%をわっているのは，金属産苇のみとなっている。東海の

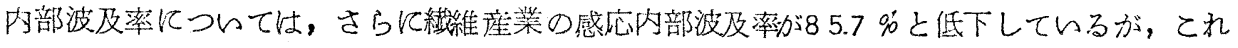

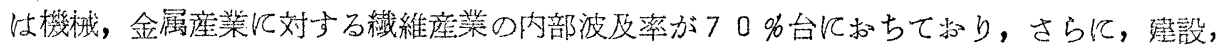

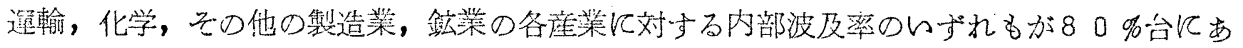
るととからもたらされた結果である。 


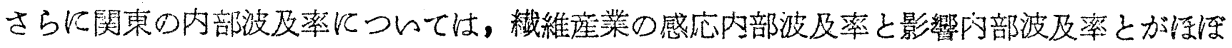
兒合っているゅえ，ささの2つとは若干様相を異にしている。こ机は，前者について，機珹，

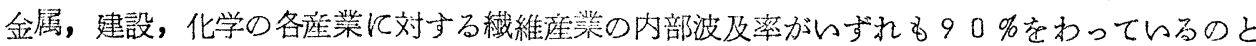

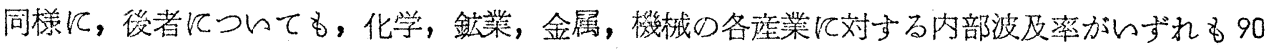
\%をわってているとよから明らかとなる。

(vii) 複投入係数による分析

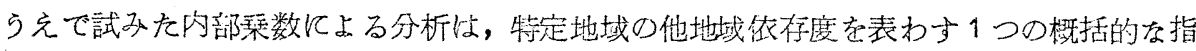

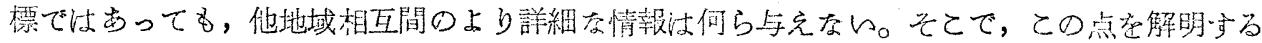
ための1手段として，われわれは，「複投入係数」という概念を提案し，それを(7)式のよらに 定義した。さらにその意義も前節で検詪したが，その骨子は，（直接的ルートにょる投入係数） 十（間接的ルートルょる投入係数）を1つの総合的な投入係数として若え，乙れ在「複投入係 数」と定議し，これによって3地域間相互の交流関係をより簡明に把握しようとするととにあ る。

表 7ー1 複投入係数表 $A_{12}^{3}$

(単位\%)

\begin{tabular}{|c|c|c|c|}
\hline \multirow{2}{*}{ 部 } & 近㙨—東海 $\left(A_{12}\right)$ & 近禨世関柬占 & \multirow{2}{*}{$(b / a) \times 100$} \\
\hline & 行和 & 行 & \\
\hline 跿 林 水 應 & 0.81 & 0.88 & 108.6 \\
\hline 策 & 0.15 & 0.18 & 120.0 \\
\hline 維 & 8. 01 & 8.61 & 107.5 \\
\hline 学 & 6.97 & 7.69 & 110.3 \\
\hline 属 & 15.53 & 17.38 & 111.9 \\
\hline 機 & 6.28 & 7. 09 & 112.9 \\
\hline その他の製造洋 & 6.42 & 7.00 & $10 \% .0$ \\
\hline 設 & 0.00 & 0.00 & $-\ldots$ \\
\hline 翰 & 1. 14 & 1. 18 & 103.5 \\
\hline そ の 他 & 4. 21 & 4.86 & 115.2 \\
\hline (平均) & 4. 95 & 5.49 & 110.8 \\
\hline
\end{tabular}


表 7-2 複投入俰数表 $A_{13}^{2}$

(単位\%)

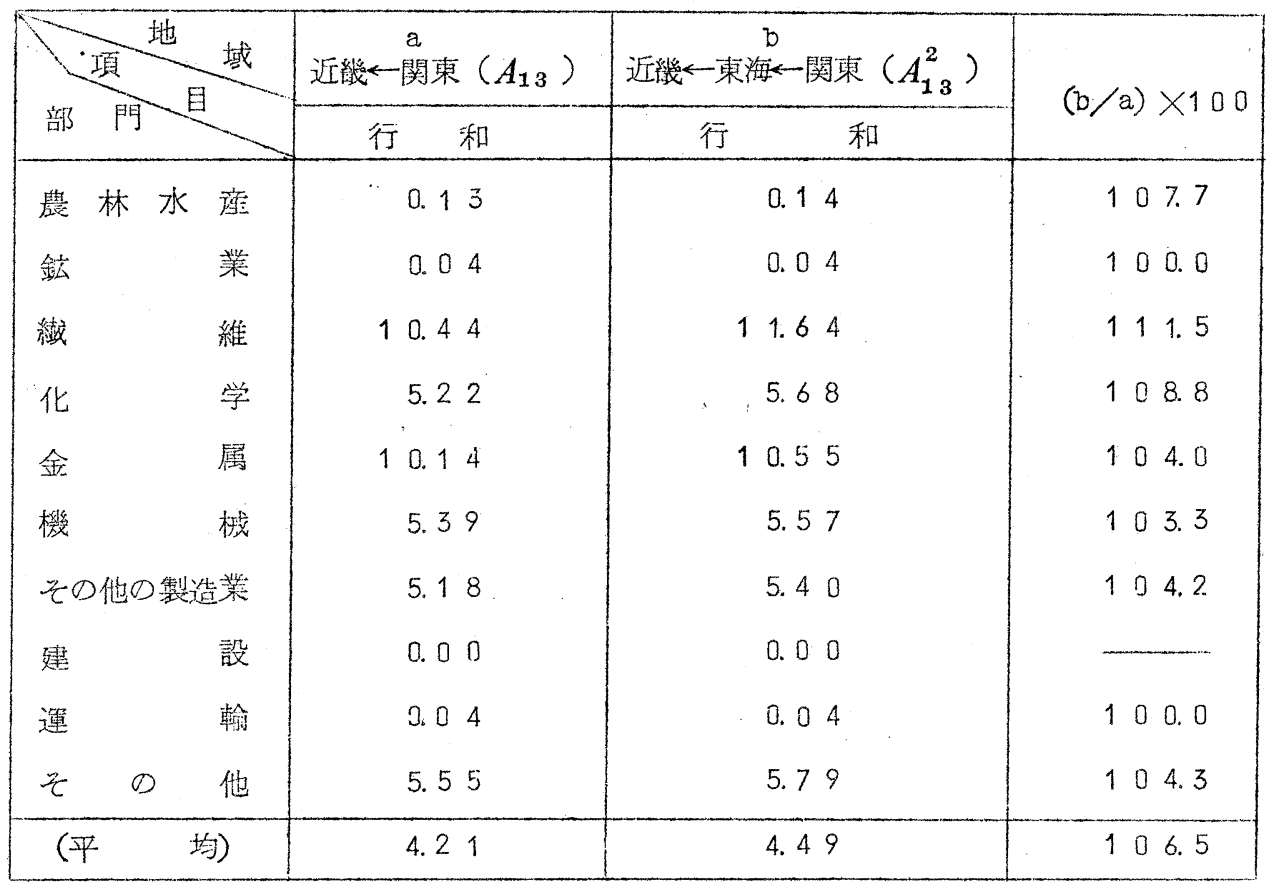

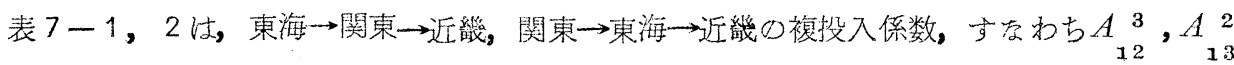
の計測結果をそれぞれをとめたものである。了地域間の交流関係を，複投入係数にるとづいて 図示すれば，つ焉の上らとなる。

図 2 複投入保数炕上る3 地域間交流関倸

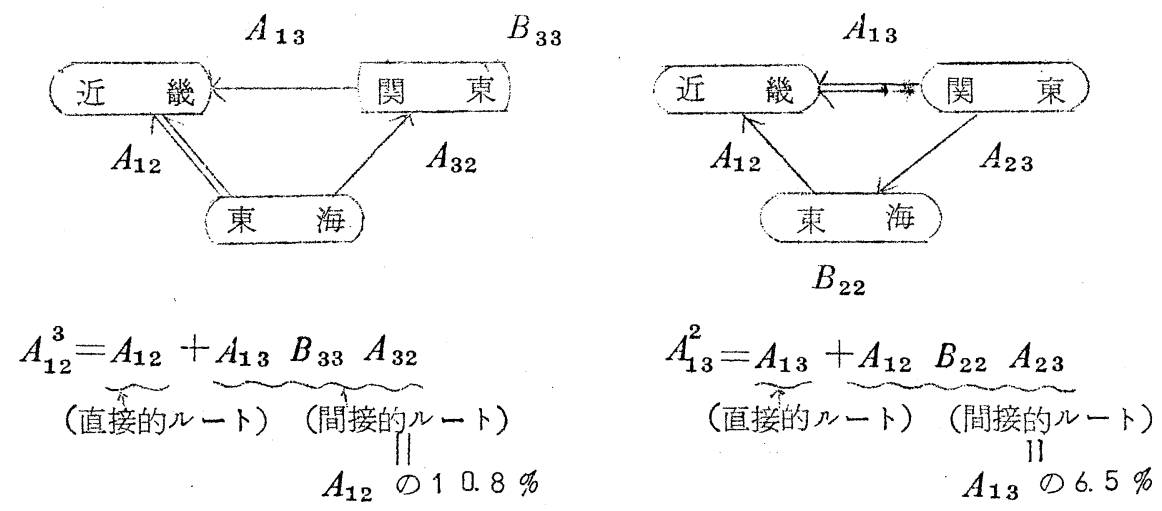

さらに以上を総合すればつづのよらな結論を導出するととがでをる。

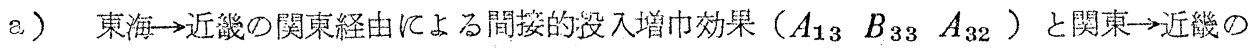
果海経由に上万间接的投入增巾効果 $\left(\begin{array}{lll}A_{12} & B_{22} & A_{23}\end{array}\right)$ にかなりの差が存在する。すなおち 
平均でみ.て前者が $10.8 \%$ 增であるのに対し，後者け6.5\%增にとどまっている。

b）その理由として2つ考えられる。1つ文，地域間投入構造の差，すなわち東海の関東産 品投入係数 $\left(A_{32}\right)$ 方関東の東海産品投入係数 $\left(A_{23}\right)$ よりも一般に大をいという專奏であ り, 第 2 の理由恃, 関東の内部乗数 $\left(B_{33}\right)$ が東海の内部乗数 $\left(B_{22}\right)$ よりも一般に大きい

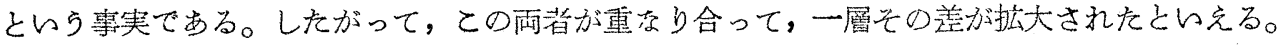
なかでも第1の理白が支配的で㤎る。

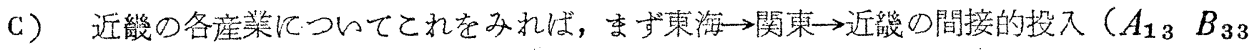

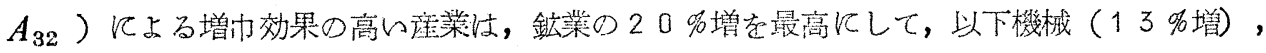

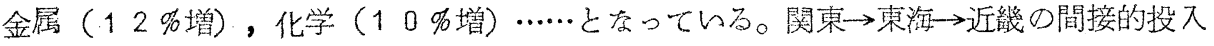

$\left(\begin{array}{lll}A_{12} & B_{22} & A_{23}\end{array}\right)$ 飞よる增巾効果の高い部門は, 繊維の1 $1.5 \%$ 增が最も高く, 他はすへ て10\%来满と盗っている。

(Viii) 複生座誘発係数による分析

こてで，特定 2 地域間の生産誘登係数(3)に詨応して，さらに第了地域への波及を考慮した

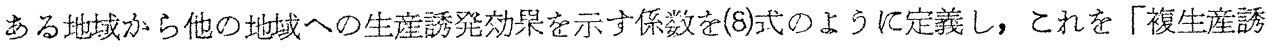
発係数」とよぶととれする。

まず，乙の意味を考えてみよう。複生産誘発係数(8)は，(6)，(7)在用々て変形すれば，

$$
\text { ( } 8 \text { ' }) \alpha_{i j}^{k}=K_{i i}^{\kappa}\left(B_{i i} A_{i j}+B_{i i} A_{i \kappa} B_{\kappa \kappa} A_{\kappa j}\right)
$$

と汸るが，右辺カッコの中の第 1 項は $j \rightarrow i$ の直接的孝生産誘発効果定示し，第 2 項は $\kappa$ 地域 在経由する間接的存生座誘発效果を示している。したがって複生座誘発係数 $\alpha \underset{i j}{\pi}$ 㳉, 直接的 ・間接的ルート资通ずる $j \rightarrow i$ の生産誘発が，第 $\kappa$ 地域との波及関係によって，さらに外部乗 数 $\left(K \begin{array}{l}K \\ i\end{array}\right)$ 倍された総効果を意味するととが明らかと就る。

表 8 は，近緭を中心とした複生座誘発係数の計測結果である。乙れをさきの局部的劣生㡾誘 発係数 $\alpha_{i j}$ (表 2 参照) と圠较すれば，第了地域経由による $j \rightarrow i$ の生産誘発の增巾効果か 判明する。

\section{(UX) 複投入誘辇係数による分析}

投入誘発の関係についても，さきの局部的な投入誘発係数(4)に対応して，「複投入唀発係数」 を考宎，てわ在(9)式のよらに定義しょう。さて，ての複投入誘発係数についても同様に変形す ればつぎのよらになる。

$$
\text { (9 ' }) \quad \beta{ }_{i j}^{\kappa}=\left(A_{i j}+A_{i \kappa} B_{\kappa \kappa} A_{\kappa j}\right) K_{j j}^{\kappa} B_{j j}
$$

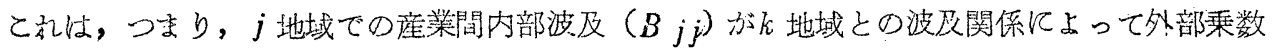


㳖 8 複生産誘発係数表 $\quad \alpha \underset{i j}{\kappa}=M_{i i}^{\kappa} A_{i j}^{\kappa}$

(単位\%)

\begin{tabular}{|c|c|c|c|c|}
\hline \multirow{2}{*}{ 部闠員地 } & \multicolumn{2}{|c|}{ 近維世関果世東海 $\left(\alpha_{12}^{3}\right)$} & \multicolumn{2}{|c|}{ 汇畿一東泚関東 $\left(\alpha_{13}^{2}\right)$} \\
\hline & 行平均 & 列平均 & 行 平 均 & 列平 均 \\
\hline 農 林 水 産 & C. 48 & 0.21 & 0.41 & 0.20 \\
\hline 鉱 & C. 19 & 0.13 & 0.13 & 0.04 \\
\hline 維 & 1.19 & 1.83 & 1.60 & 2.75 \\
\hline 学 & 1. 18 & 0.40 & 0.91 & 0.38 \\
\hline 属 & 3.52 & $1.6 \mathrm{D}$ & 2. 20 & 1. 01 \\
\hline 械 & 0.98 & 2.27 & 0.77 & 1.60 \\
\hline その他の製造栄 & 1.07 & 0.85 & 0.86 & 0.52 \\
\hline 設 & 0.06 & 2. 23 & 0. 05 & 1.35 \\
\hline 運 & C. 30 & 0.40 & 0.15 & 0.32 \\
\hline D 他 & 1.50 & 0.52 & 1. 42 & 0.33 \\
\hline 均) & 1. 04 & 1. 04 & 0. 85 & 0.85 \\
\hline
\end{tabular}

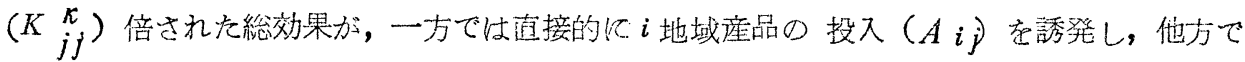

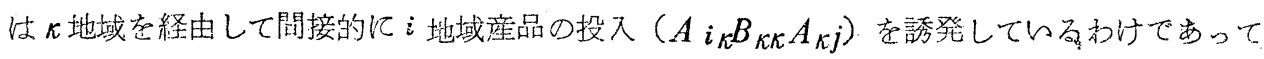
直接的・間接的両ルートを通ずる $j \rightarrow i$ の投入誘発速関の総効果が，複投入誘発係数として把 えられているのである。

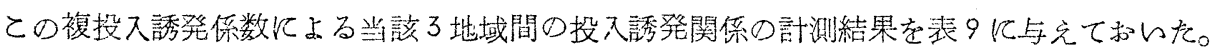
したがって，柰えと同様に局部的投入唀発係数 $\beta_{i j}$ (表了参照) との比較による增巾効果の 検討加可能となるであるう。

〔脚部〕

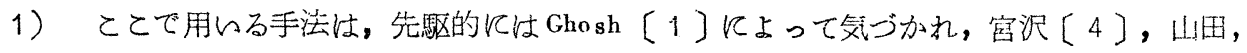

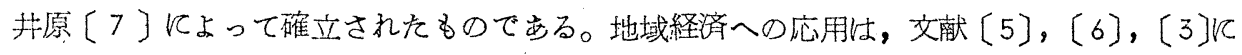
上って試みられている。

2）各式の導出の仕方は，文献(7)を参照されたい。

3) 本節での計算は, 京都大学工学部電子計算機H I T A C 5020 (K DCーII) Kよって行なっ

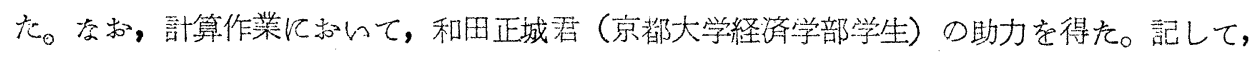
謝意を表する。 
表 9 複投入誘発你数嗝

$$
\beta_{i j}^{\kappa}=A_{i j}^{\kappa} M_{j j}^{\kappa}
$$

(策位. \%)

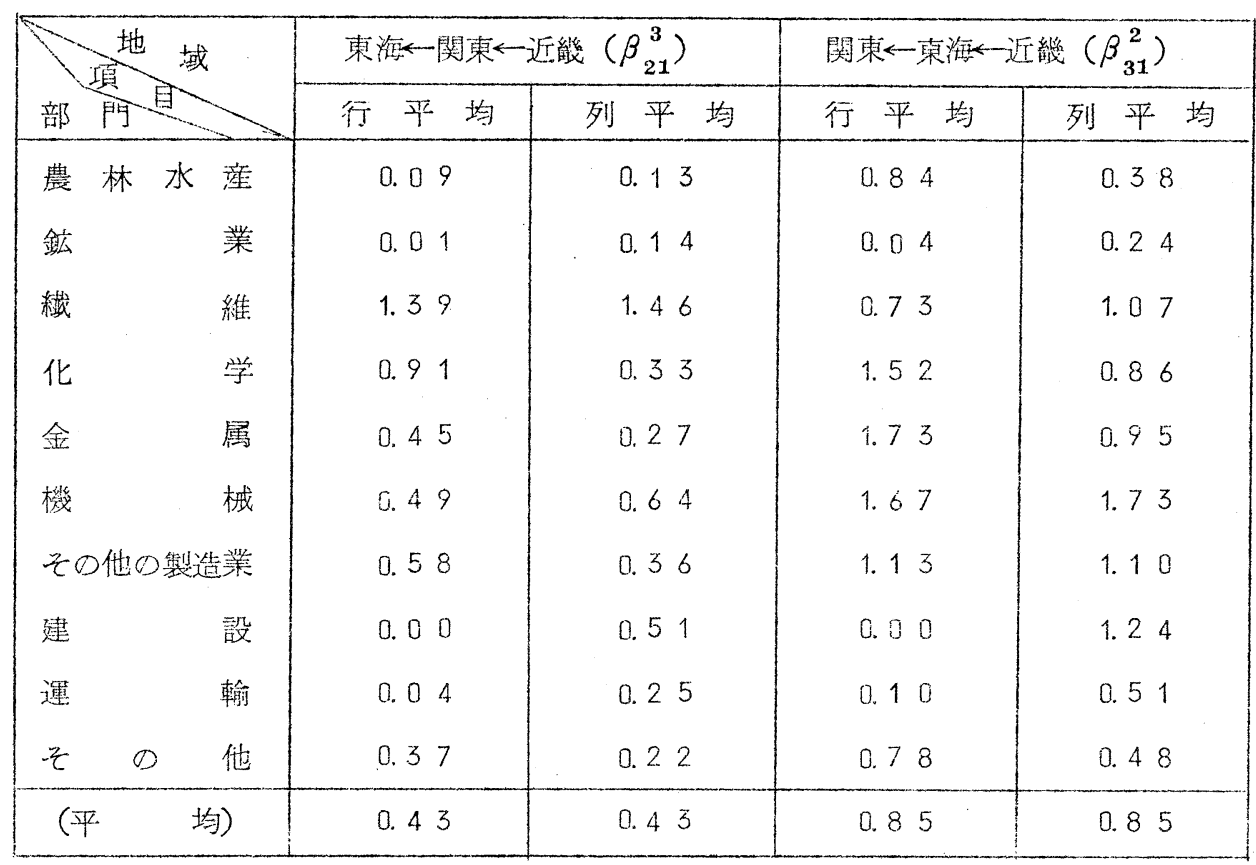

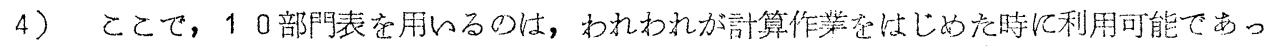
たのがイ ○部門表であったととが主をる理由でする。

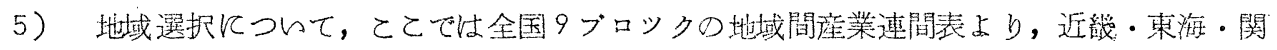

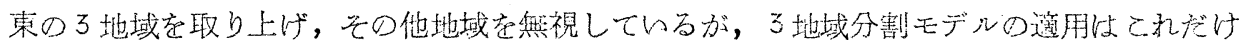

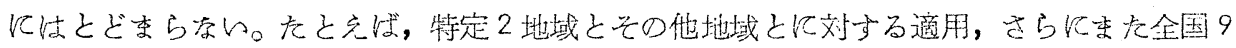

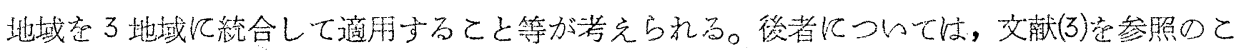
¿。

6) 乙とでは， $\alpha_{12}$ と $\beta_{21} * \alpha_{13}$ と $\beta_{31}$ との比較を行なっているが，さらに $\alpha_{12}$ に対して 壮 $\alpha_{21}, \beta_{21}$ に対しては $\beta_{12}$ との比較による分所有意存ものとなる。

7) $A_{21}$ と $A_{21}^{3}, A_{31}$ と $A_{31}^{2}$ との比較による間接的投入增巾効果は, 平均でみて剖者が 10.0 \%であるのに対し，後者が5.5\%となっている。したがって，ての事実より，a）の結論は， 双方通行的红妥当标方と考六られる。 
参考文献

[1] Ghosh, A., 'Input-Output Analysis With Substantially Independent Groups of Industries', Econometrica, 1960.

(2) Leontief, W. W., 'The Structure of American Economy', Ist ed., 1941，2nd ed., 1951，山田勇・家本秀太郎訳「アメリカ経済の棈造」， 19590

〔3〕通産大臣官房調査統計部，「昭和３５年地域間産業連関表による日本経済の地域連関分 析」 1960 。

〔4〕宮沢健一, 「経済構造の連関分析」1963。

〔5〕宮沢健一，「地域経済と産業連関の搆造」，横浜市大諭叢 1964 年 3 月号。

〔6〕宮沢健一, 「地域経済の速関モデルとその道用」, 調査月報1965年1月。

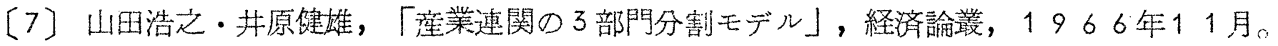


Input-Output Analysis of Interregional Repercussion

Hiroyuki Yamada (Kyoto Univ.)

Takeo Thara (Kagawa Univ.)

This paper concerns the following problem: in the usual interregional input-output analysis, the inverse matrix only shows the ultimate total effects of interregional propagation, but we cannot draw any information on the partial interactions between two or three regions which might be thought to have structurally different characters. How, then, is it best taken into account?

This paper cen be divided into two parts. In the first part, we consider the theoretical framework to clarify the problem of this type. There, we formulate the "general model partitioned into three regions", with meaningful notions.

In the second part, we apply our formula to the Interregional Input-Output Model of the Japanese Economy. Some empirical findings of this study are summarised there. 